\title{
THE EFFECT OF MARINE SPONGE Aaptos aaptos EXTRACT IN VIBRIOSIS TREATMENT OF BLACK TIGER SHRIMP Penaeus monodon LARVAE
}

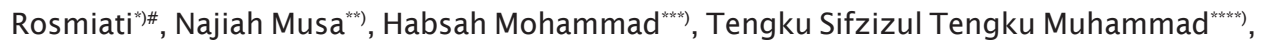 \\ Andi Parenrengi*), and Wahyuni ${ }^{* * * * * *}$ \\ "Research and Development Institute for Coastal Aquaculture, Maros \\ *) Department of Aquaculture Science, Faculty of Fisheries and Aqua-Industry, Universiti Malaysia \\ Terengganu, Malaysia \\ ${ }^{* * *}$ Institute of Marine Biotechnology, Universiti Malaysia Terengganu, Malaysia \\ *wate) Department of Biological Science, Faculty of Science and Technology, Universiti Malaysia \\ Terengganu, Malaysia \\ Disease Investigation Center, Maros, Indonesia
}

(Received 19 March 2014; Final revised 18 September 2014; Accepted 10 November 2014)

\begin{abstract}
Black tiger shrimp Penaeus monodon post larvae were challenged with Vibrio harveyi and butanol extract of selected marine sponge Aaptos aaptos to determine its antibacterial bioactive potential in vibriosis treatment. Based on the preliminary toxicity study, the $A$. aaptos butanol extract with concentrations of $31.25,62.5$, and $125 \mathrm{mg} / \mathrm{L}$ were selected in the study. Black tiger shrimp post larvae were challenged with $V$. harveyi at $10^{7} \mathrm{cfu} / \mathrm{mL}$ and immersed $A$. aaptos butanol extract with the concentration of $125 \mathrm{mg} / \mathrm{L}$ showed significantly in $(P<0.05)$ decrease mortality of the post larvae treated. Besides at this concentration, $V$. harveyi population in the rearing water and the post larvae treated decreased compared to control (untreated post larvae). Histological observation indicated that there was no changing on hepatopancreas of the black tiger shrimp post larvae. Based on this result, it is suggested that the butanol extract of $A$. aaptos is a potential bioactive compounds source in the treatment of vibriosis which may replaced the current antibiotics application.
\end{abstract}

KEYWORDS: Aaptos aaptos, marine sponge, Penaeus monodon, vibriosis

\section{INTRODUCTION}

Vibriosis luminescence is one of bacterial diseases caused by Vibrio species. This disease has been the main causative agent of mass mortality in shrimp culture. Vibriosis has resulted in mass mortality of larva and postlarval stages of Penaeus monodon rearing systems (Sarjito et al., 2012). Mortalities of P. mo- nodon larvae associated with luminescence have been observed in hatcheries in Indonesia (Kadriah, 2012), Thailand (Pasharawipas, 2011 ) and Philippines (Traifalgar et al., 2013). Among the causative agents of Vibriosis, Vibrio harveyi (luminescent bacterium) often results in mass mortality of $P$. monodon larval rearing systems (Ramesh et al., 2014). The pres-

\# Corresponding author. Research and Development Institute for Coastal Aquaculture Jl. Makmur Dg. Sitakka No. 129, Maros 90512, Sulawesi Selatan, Indonesia. Phone: +62 411371544 E-mail: litkanta_05@gmail.com 
ence of $V$. harveyi at density of $10^{7} \mathrm{cfu} / \mathrm{mL}$ in the rearing water was reported to cause mortality in black tiger shrimp $P$. monodon post larvae 14 days ( 14 days post larvae) (Kadriah, 2012).

Current treatments of vibriosis are largely based on the use of potent antibiotics, but currently their efficacy is low, very poor. The use of antibiotics has been less effective and resulting in severe side effects in the rearing environment, shrimp and human, and even death in shrimp (Raffi \& Suresh, 2011 ). Several disadvantages of antibiotics are the presence of antibiotic-resistant bacteria (Kumar et al., 2014), antibiotics residue which may accumulate in the shrimp, upsetting the chemical balance in the ponds by affecting useful organisms like nitrifying bacteria and killing food organisms, and concerns of antibiotic resistance to human pathogens (Hettiarachchi et al., 2005).

Marine organisms are a rich source of biological diversity and potential for discovery of novel drugs (Ninawe, 2007). Among marine organisms, sponge is the richest of both biologically active secondary metabolites and chemical diversity. Several species of sponges were described to have antibacterial properties against vibriosis treatment such as Geodia sp. (Isnansetyo et al., 2009) and Denrillanigra (Selvin \& Lipton, 2004). This study aims to determine the potentiality of Aaptos aaptos butanol extract as bioactive compounds source in the treatment of vibriosis due to Vibrio harveyi in tiger shrimp post larvae.

\section{MATERIALS AND METHODS}

\section{Acclimatization of Post Larvae}

Seven days post larvae (PL-7) of black tiger shrimp, Penaeus monodon were collected from a commercial hatchery in Bone Regency, South Sulawesi, Indonesia. They were stocked in fibre glass tank $(500 \mathrm{~L})$ in the wet laboratory of Research and Development Institute for Coastal Aquaculture (RICA), Maros, Indonesia. The shrimp post larvae were acclimatized in the temperature-controlled wet laboratory and reared for seven days prior to starting of experiment ( $\mathrm{PL}-14)$. During the rearing period, they were fed with commercial feed at $10 \%$ of body weight twice a day (06.00 and 18.00). The post larvae which were free of white spot (based on PCR test) and around $1 \mathrm{~cm}$ length size were selected.

\section{Extract Preparation}

Sponge Aaptos aaptos was collected from Barrang Lompo Islands, South Sulawesi latitude (-5.047 degrees) $5^{\circ} 2^{\prime} 49^{\prime \prime}$ South of the Equator and longitude (1 19.329 degrees) $119^{\circ} 19^{\prime} 44^{\prime \prime}$ East of the Prime Meridian on the Map of the world by SCUBA diving at the depth of 8-12 m on $16^{\text {th }}$ August 2010 . Sponges were kept in sealed plastic bag and placed in cool box on fresh condition and brought to Biotechnology Laboratory of RICA, Maros. The fresh sponge was cut into small pieces and oven dried at $37^{\circ} \mathrm{C}$ for three days. It was then grinded into powder and extracted with methanol using a forma orbital shaker at $37^{\circ} \mathrm{C}$ till the residue became colourless. The methanolic extracts was filtered through Whatmann No. 1 filter paper fitted in a Buchner funnel using suction and collected for concentrated under reduce pressure by a rotary evaporator (Buchi-type) to yield a dark gummy solid. Later, salt was removed from methanol extract using HP-20 while lipid/waxes were removed using C- 18 catridge as described by Rosmia et al. (2011) to get interference material free methanolic extract.

\section{Partitioning of Methanolic Extract}

The interference material free methanolic extract above was added with distilled water and partitioned with diethyl eter and 1-butanol to give diethyl eter, butanol, and aqueous extract. The butanol extract obtained was diluted in distilled and sterilized seawater $(30 \mathrm{~g} / \mathrm{L})$ to get a concentration of $32.25,62.5$, and 125 $\mathrm{mg} / \mathrm{L}$ based on the preliminary toxicity experiment.

\section{Challenge Test Activity}

\section{Preparation of Vibrio harveyi}

Vibrio harveyi culture (MR 275 Rif) being used was a collection of RICA, Maros, Indonesia with the density of $10^{7} \mathrm{cfu} / \mathrm{mL}$. Preparation of $V$. harveyi was done as described by Kadriah et al. (2012). One hundred $\mu \mathrm{L}$ of glycerol : nutrient broth $(1: 1)$ containing the bacterium isolate was cultured in $10 \mathrm{~mL}$ nutrient broth (NB) and incubated at $28^{\circ} \mathrm{C}$ on orbital shaker (forma type), $150 \mathrm{rpm}$ for 24 hours. One $\mathrm{mL}$ of starter culture was transferred to $400 \mathrm{~mL} \mathrm{NB}$ and incubated using shaker at $150 \mathrm{rpm}, 28^{\circ} \mathrm{C}$ for four hours to obtain the density of bacterium of $10^{8}$ $\mathrm{cfu} / \mathrm{mL}$. The bacterium was diluted in Nutrient Broth to get the density of $10^{7} \mathrm{cfu} / \mathrm{mL}$ before used. 


\section{Challenge Test}

Soaking method as described by Kadriah (2012) with some modifications was used for challenge test. The larval rearing units were consisted of conical shaped aquaria containing $1 \mathrm{~L}$ filtered and chlorinated seawater at 30 $\mathrm{g} / \mathrm{L}$. The density of 14 days-old post larvae was 20 larvae/L for each unit. In this study, Completely Randomized Design being used were five treatments with three repetitions. The five treatments were consisted of: (A) positive control $\mathrm{PL}+V$. harveyi; (B) $\mathrm{PL}+\mathrm{V}$. harveyi + $31.25 \mathrm{mg} / \mathrm{L}$ extract; (C) PL + V. harveyi +62.5 $\mathrm{mg} / \mathrm{L}$ extract, (D) $\mathrm{PL}+\mathrm{V}$. harveyi $+125 \mathrm{mg} / \mathrm{L}$ extract, and (E) negative control (PL without $V$. harveyi and extract). During this study, all rearing units were provided with gentle, continuous aeration, and without water exchange. In addition, the post larvae were fed with commercial feed at $10 \%$ of body weight twice a day (06.00 and 18.00).

\section{Data Collection}

The mortality or survivability of post larvae in the water rearing was monitored at $1,3,6,9$, $12,24,36,48,72$, and 96 hours post-treatment. The enumeration of $V$. harveyi in the rearing water was calculated in the initial, one and every three hours for the first 24 hours, continued in every 24 hours up to four days whilst in the post-larvae was calculated in 6,12 , and 24 hours, continued in every 24 hours post-treatment up to four days. The clinical signs were also observed during the rearing. In addition, water quality parameters such as, $\mathrm{pH}$, temperature, and dissolved oxygen were also measured in the initial, mid, and the end of this study as supporting data. At the initial of six hour and the end of experiment, three larvae were harvested and fixed in $10 \%$ buffered formalin solution and then were subjected to standard histology processing as described by Sarma \& Devi (2012) with some modification.

The enumeration of $V$. harveyi population in post larvae and rearing water was done using total plate count (TPC) with spread plate method. The enumeration of $V$. harveyi in rearing water was done taking out $1 \mathrm{~mL}$ rearing water of every treatment and diluted in $9 \mathrm{~mL}$ sterile saline solution $(0.85 \% \mathrm{NaCl})$ and assigned as the original solution or dilution factor $\left(10^{\circ}\right)$. Meanwhile, in the post larvae was done by harvesting two post larvae from every treatment, cleaning of the surface with alcohol containing cotton, grinding, and dilut- ing in $10 \mathrm{~mL}$ sterile saline solution $\left(10^{\circ}\right)$. Serial dilutions of the original culture tube were prepared by transferring $1 \mathrm{~mL}$ of culture into a 9 $\mathrm{mL}$ of sterile saline solution, mixing and removing from this solution $1 \mathrm{~mL}$ to be transferred to another $9 \mathrm{~mL}$ sterile saline solution to obtain the dilution factor of $10^{-1}$ and continued until the dilution factor $10^{-7}$ of the original bacterial suspension. One hundred $\mu \mathrm{L}(0.1 \mathrm{~mL})$ of each dilution was dispensed into two plates of 100 $\mathrm{mg} / \mathrm{L}$ rifamphycine containing TCBS Agar and spread it in duplicate with the same bent glass rod. The plates then were inverted and incubated at $28^{\circ} \mathrm{C}$ for 24 hours. Those duplicate plates which had 30 to 300 colonies were counted individually. The mortality percentage was counted by the following equation.

$$
\text { Mortality }(\%)=\frac{\mathrm{Nt}}{\mathrm{No}} \times 100 \%
$$

where:

$\mathrm{Nt}=$ Number of dead post larvae

No $=$ Total number of the initial post larvae

The enumeration of $V$. harveyi population $(V h P)$ was counted by equation as followed:

$$
V h P(C F U / m L)=A \times \frac{1}{V} \times \frac{1}{P}
$$

where:

$A=$ Total of colony (CFUs)

$\mathrm{V}$ = Volume of bacterium which was spread on agar $(\mathrm{mL})$

$\mathrm{P}=$ Dilution factor

\section{Data Analysis}

Analysis of mortality/survivability data was performed by one way analysis of variance (ANOVA). When differences were found among the treatments, Tukey's test was used to compare means by SPSS Version 15.0 software packages (SPSS ${ }^{\circledR}$ Inc., USA). Differences of results were considered statistically significant difference if the $P$ value were 70.05 . Whilst, clinical signs, enumeration of $V$. harveyi in water rearing and post-larvae and water quality were analyzed descriptively. The analysis of any adverse effect in tissue was observed via histological examination.

\section{Results and Discussion}

The mortality rate of tiger shrimp, $P$. monodon post larvae (Table 1) showed that there 
Table 1. Mortality of black tiger shrimp, P. monodon post larvae challenged with $V$. harveyi and different concentrations of Aaptos aaptos butanol extract during the rearing period

\begin{tabular}{lccccccccccc}
\hline \multirow{2}{*}{\begin{tabular}{c} 
Concent rations $(\mathbf{m g} / \mathrm{L})$ \\
\cline { 2 - 27 }
\end{tabular}} & T1 & T3 & T6 & T9 & T12 & T24 & T36 & T48 & T72 & T96 & Total \\
\hline 0 (Control) & 0 & 13.3 & 26.7 & 6.7 & 6.7 & 3.3 & 3.3 & 10 & 3.3 & 6.7 & 80 \\
31.25 & 0 & 6.7 & $13.3^{*}$ & 3.3 & 10 & 6.7 & 10 & 6.7 & 6.7 & 6.7 & 70 \\
62.5 & 0 & $0^{*}$ & $6.7^{*}$ & 6.7 & 10 & 13.3 & 0 & 10 & 10 & 10 & 66.7 \\
125 & 0 & $0^{*}$ & $0^{*}$ & 0 & $0^{*}$ & 0 & 10 & 10 & 10 & 13.3 & $43.3^{*}$ \\
\hline
\end{tabular}

Percentage of mortality with (") are significantly different $(\mathrm{P}<0.05)$ as compared to control

was no difference among all the concentrations of Aaptos aaptos butanol extract used at $1,9,24,36,48,72$, and 96 hours post treatment compared to control. Nevertheless, the mortality rate significantly decreased at 3,6 , and 12 hours post treatment in which the post larvae treated with the extract at the concentration of 62.5 and $125 \mathrm{mg} / \mathrm{L}$ exhibited a significantly different mortality and all the concentrations were significantly difference on 3 and 6 hours post treatment, respectively. Meanwhile, at 12 hours post treatment only the post larvae being treated with the extract with the concentration of $125 \mathrm{mg} / \mathrm{L}$ gave a significantly difference compared to the control. The highest mortality rate $(80 \%)$ in the end of this experiment was obtained in the untreated post larvae (control), followed by 31.25 , 62.5 , and $125 \mathrm{mg} / \mathrm{L}$ with the mortality rate of $70 \%, 66.7 \%$, and $43.3 \%$, respectively with the significant difference was obtained on the treatment of $125 \mathrm{mg} / \mathrm{L}$ and two other concentrations gave a similar mortality effect compared to control. The efficacy shown by this Aaptos aaptos butanol extract concentration in decreasing the tiger shrimp post larvae mortality at 12 hours post treatment was the same result as antibiotic oxytetracyline treatment with the concentration of $40-50 \mathrm{mg} / \mathrm{L}$ (Mariyono et al., 2002). Nevertheless, after 96 hours of the treatment its efficacy in the total decreasing of mortality was less lower than probiotic BL 542 bacteria isolate application which gave mortality of 42\% (Muliani et al., 2005 in Agung, 2007). Penaeus monodon larvae infected by vibriosis commonly suffered mortalities within 48 hours of immersion challenged with strains of $V$. harveyi and $V$. splendidus whilst, the mass mortality of larvae was occurred in the period of 1-3 days since the clinical signs of vibriosis observed (Kadriah, 2012).
Population of $V$. harveyi also decreased in the rearing water of the post larvae treated with Aaptos aaptos butanol extract of all the concentrations during the rearing period (Figure 1). Population of $V$. harveyi in the rearing water treated with butanol extract at the concentration of 31.25 and $62.5 \mathrm{mg} / \mathrm{L}$ after one hour infection gave a maximum growth namely, $7.5 \times 10^{7}$ and $5.3 \times 10^{7} \mathrm{cfu} / \mathrm{mL}$. Meanwhile, control showed the highest bacteria growth of $1.91 \times 10^{8} \mathrm{cfu} / \mathrm{mL}$ after three hours post infection. In contrast, a drastic decreasing of $V$. harveyi population $\left(9.3 \times 10^{5} \mathrm{cfu} / \mathrm{mL}\right)$ was exhibited by butanol extract treatment with the concentration of $125 \mathrm{mg} / \mathrm{L}$. In general, population of $V$. harveyi in the rearing water was seemed to decrease drastically after six hours post infection for all the post larvae treated.

Population of $V$. harveyi in black tiger shrimp post larvae after treatment of Aaptos aaptos butanol extract was also lower than control (Figure 2). The maximum growth of $V$. harveyi on all treatments of $A$. aaptos butanol extract was found six hours after challenged with $V$. harveyi and continued to decrease until the end of study. The lowest Vibrio harveyi population was obtained on the treatment of $A$. aaptos butanol extract with the concentration of $125 \mathrm{mg} / \mathrm{L}\left(1.77 \times 10^{3} \mathrm{cfu} / \mathrm{mL}\right)$, followed by $62.5 \mathrm{mg} / \mathrm{L}\left(4.13 \times 10^{4} \mathrm{cfu} / \mathrm{mL}\right)$ and $31.25 \mathrm{mg} / \mathrm{L}$ $\left(6.13 \times 10^{4} \mathrm{cfu} / \mathrm{mL}\right)$. In contrast, the highest was showed by control (without butanol extract) namely; $1.51 \times 10^{6} \mathrm{cfu} / \mathrm{mL}$. The decreasing of $V$. harveyi population in post larvae and rearing water showed that butanol extract was able to inhibit the growth of $V$. harveyi population which caused increasing immune system of black tiger shrimp post larva to defend against bacterial infection. A. aaptos butanol extract at the concentration of 31.25 and 62.5 


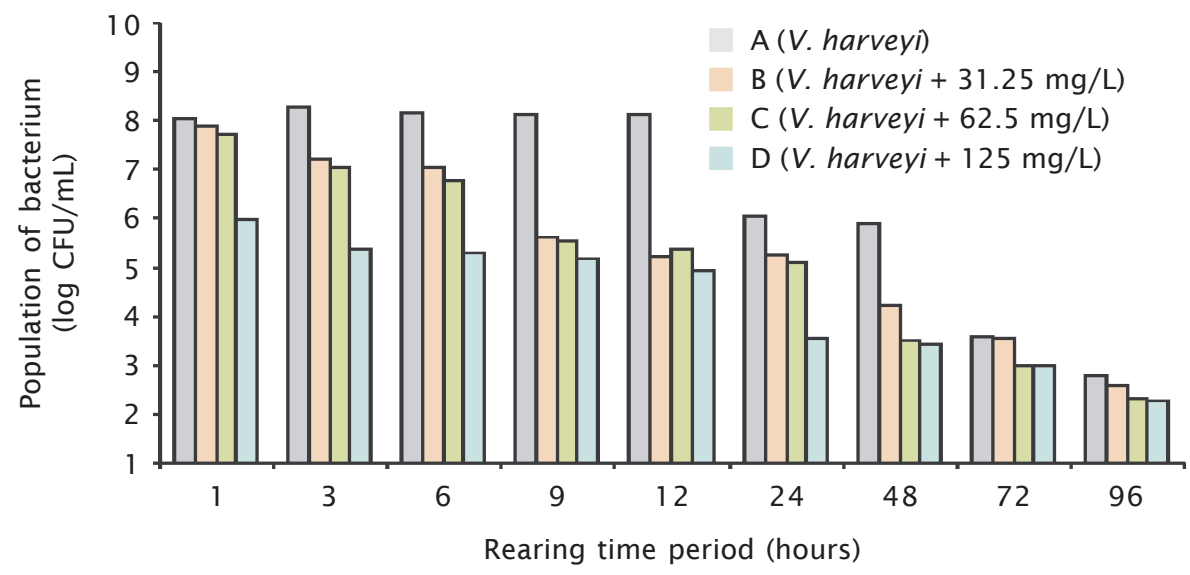

Figure 1. Population of $V$. harveyi in the rearing water treated with different concentration of Aaptos aaptos butanol extract during the rearing time period

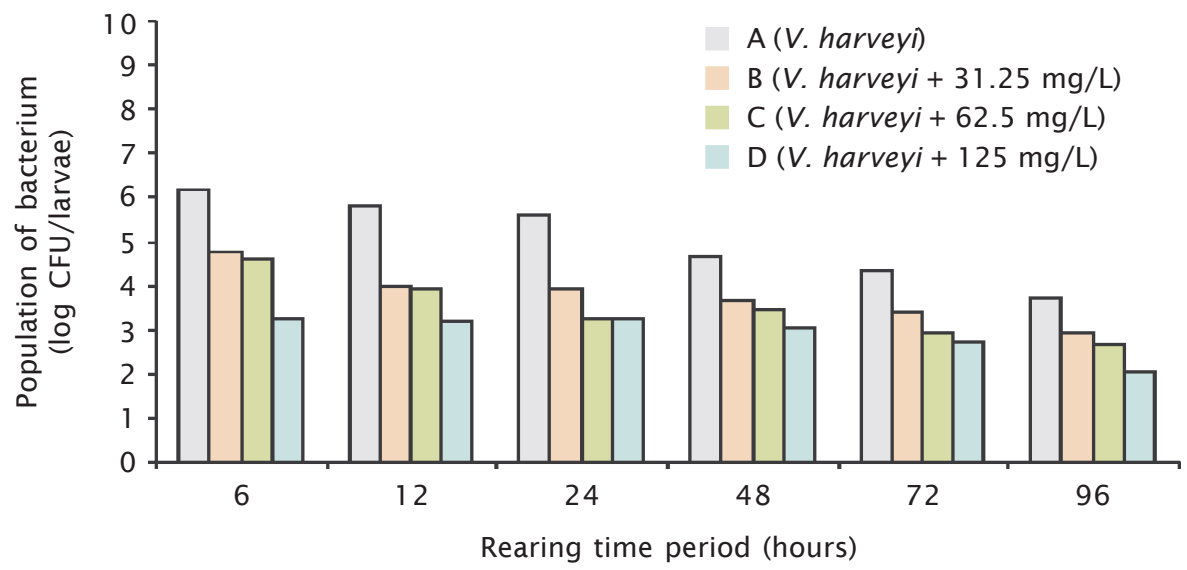

Figure 2. Population of $V$. harveyi in the post larvae treated with different concentration of Aaptos aaptos butanol extract during the rearing time period

$\mathrm{mg} / \mathrm{L}$ also decreased the population of $\mathrm{V}$. harveyi. However, they were not able to prevent the infection of this bacterium due to the low concentration. The weak antibacterial shown by $A$. aaptos butanol extract at the concentration of 32.25 and $62.5 \mathrm{mg} / \mathrm{L}$ caused the high mortality of post larvae. The antibacterial shown by butanol extract of $A$. aaptos was caused by the presence of alkaloid compounds. As it was well known that majority of A. aaptos compounds is alkaloid. Guittat et al. (2003) demonstrated that alkaloid fight against bacteria by inhibiting certain vital processes of bacterial cells or metabolism.

Clinical signs observation on tiger shrimp post larvae during challenge test with $V$. harveyi showed behavior and morphology change. The behavior change on the post larvae treated with Aaptos aaptos butanol extract at the concentration of 31.25 and $62.5 \mathrm{mg} / \mathrm{L}$ was indicated by decreasing to low appetitive and erratic swimming. The same signs were also exhibited by positive control. Meanwhile, the post larvae treated with Aaptos aaptos butanol extract at the concentration of $125 \mathrm{mg} / \mathrm{L}$ did not show any abnormal behavior as displayed by negative control, except on the fourth day, the post larvae showed a low appetitive which was suspected due to molting. As reported by Ramesh et al. (2014) post larvae suffering vibriosis are anorexia, lethargy, jumping to the surface, passive, slow swimming, more feed resi- 
due, red feces, red or brown hepatopancreas. The morphology change observed six hours post treatment and it was indicated by red discoloration body on the positive control and the treatment of $125 \mathrm{mg} / \mathrm{L}$ while it became dull and dirty on the treatment of 31.25 and 62.5 mg/L. After 96 and 168 hour of Aaptos aaptos butanol extract treatment, the post larvae treated with $125 \mathrm{mg} / \mathrm{L}$ showed behavior and morphology back to normal. Meanwhile, the post larvae treated with the concentration of 32.25 and $62.5 \mathrm{mg} / \mathrm{L}$ were still dull and dirty. Except for the post larvae treated with 125 $\mathrm{mg} / \mathrm{L}$, all the post larvae had died 168 hours post treatment.

The observation of water quality during challenge test period (Table 2 ) was suitable for the growth of tiger shrimp post larvae. Soundarapandian et al. (2009) reported that for optimum growth of Penaeus monodon, the optimum temperature was between $25^{\circ} \mathrm{C}-31^{\circ} \mathrm{C}$ and the optimum dissolved oxygen was between 4-8 mg/L. Meanwhile, Parado-estepa et al. (1996) reported that the optimum $\mathrm{pH}$ for $P$. monodon is 7.5 to 8.5 .

Results of the histopathological examination on hepatopancreas of black tiger shrimp post larvae challenged with Vibrio harveyi and treated with different concentration of Aaptos aaptos butanol extract six hours post treatment in this study (Figure 3) showed the changes in cells and tissue morphology due to pathogen infection. The changes in cells and tissue morphology observed on control (A) were the presence of necrosis cells and the existence of haemocytic nodule formation (hemorrhage) as well as atrophy of the hepatopancreas. The cells necrosis were also exhibited by the treatment of Aaptos aaptos butanol extract with the concentration of 32.5 $\mathrm{mg} / \mathrm{L}$ (B) and $62.5 \mathrm{mg} / \mathrm{L}$ (C). Nevertheless, more necrosis cells were observed on treatment B compared to $C$. Meanwhile, fatty degeneration observed in treatment B was not caused by the pathogenity of Vibrio harveyi but it was due to malnutrition. According to Ambipillai et al. (2003), severe hepatopancreatic pathology typical of enteric vibriosis are cells necrosis, haemocytic nodule formation (hemorhage), and atropy. In contrast, the observation on treatment $D$ showed a normal hepatopancreas i.e. lumen containing a granular material and the lumen-facing surface on the tubule was covered with a microvillus border. Besides that, the tubular apex was contained undifferentiated embryonic cells (E cells). R (Restzellen), B (Blasenzellen), and F (Fibrillazellen) cells were also observed while $F$ cells nuclei were larger than those of R cells which characteristically contained numerous of nuclei.

The similar histological observation was also showed after 96 hours treatment (Figure 4 ), control displayed not only cells necrosis, haemorrhagy, and atropy but also lysis on hepatopancreas. Cells necrosis were also observed on treatment $C$ whilst, on treatment $B$ haemorrhagy were occurred besides cells necrosis. In contrast, we observed a normal hepatopancreas on treatment D. According to Jiravanichpaisal et al. (1994) histophatological observation of shrimps/post larva suffering vibriosis shows systemic vibriosis typically results in the formation of septic haemocytic nodules in the lymphoid organ, heart and connective tissues of the gills, hepatopancreas, antennal gland, nerve cord, telson, and muscle. Infected hepatopancreas may appear poorly vacuolated indicating low lipid and glycogen reserves and atrophy of multifocal hepatopancreas with necrosis and inflammation. Vibriosis in Penaeus monodon is associated with the formation of "spheroids" in the lymphoid organ (Nash et al., 1992).

Table 2. The water quality observation of tiger shrimp post larvae challenged with $V$. harveyi and different concentration of butanol extract for four continues days

\begin{tabular}{lccc}
\hline $\begin{array}{c}\text { Extract concentration } \\
(\mathbf{m g} / \mathrm{L})\end{array}$ & $\mathbf{p H}$ & $\begin{array}{c}\text { Temperat ure } \\
\left({ }^{\circ} \mathrm{C}\right)\end{array}$ & $\begin{array}{c}\text { Dissolved oxygen } \\
(\mathbf{m g} / \mathrm{L})\end{array}$ \\
\hline 0 (Control) & $7.19-7.99$ & $26.3-26.4$ & $7.77-7.80$ \\
31.25 & $7.54-8.07$ & $26.2-26.4$ & $6.89-7.74$ \\
62.5 & $7.45-7.90$ & $26.3-26.4$ & $7.07-7.23$ \\
125 & $7.80-8.08$ & $26.2-26.3$ & $7.06-7.22$ \\
\hline
\end{tabular}



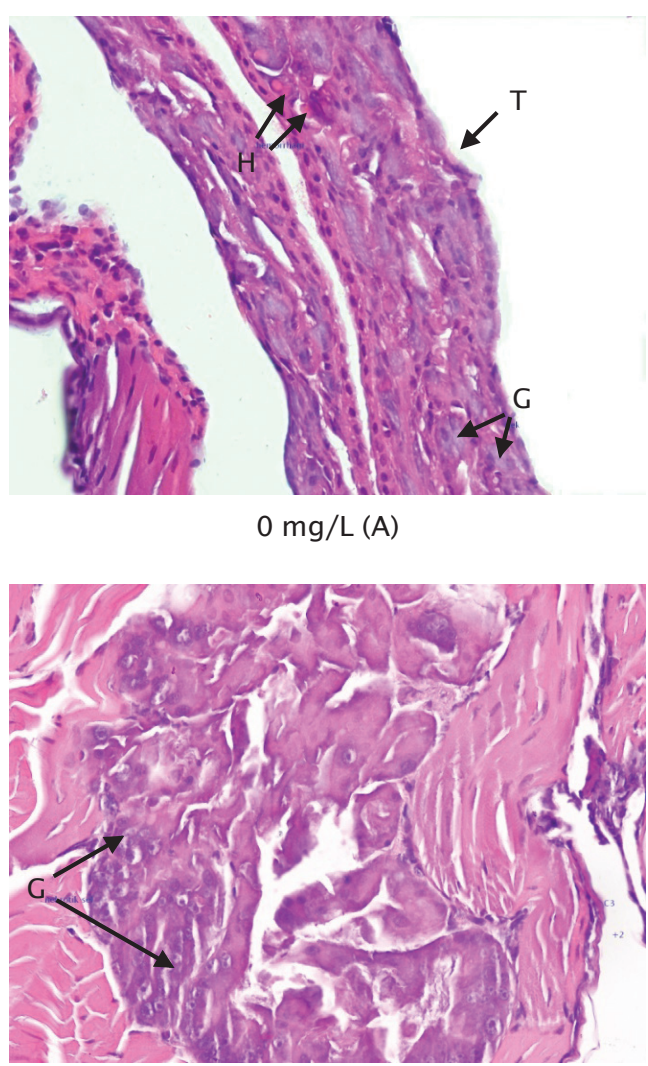

$62.5 \mathrm{mg} / \mathrm{L}(\mathrm{C})$

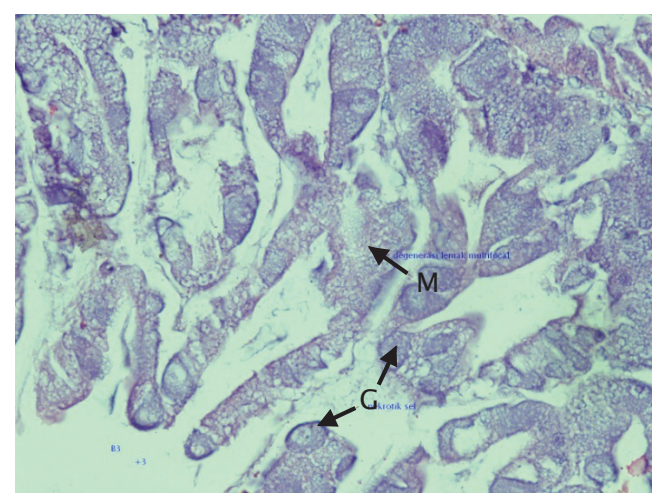

$31.25 \mathrm{mg} / \mathrm{L}(\mathrm{B})$

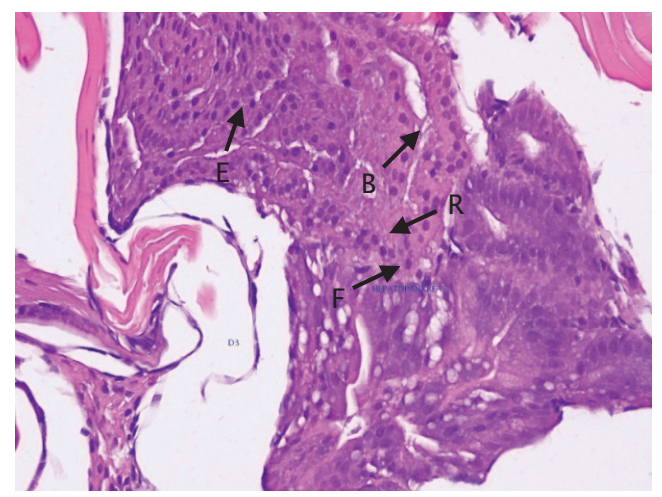

$125 \mathrm{mg} / \mathrm{L}(\mathrm{D})$

Figure 3. Histological observation of Aaptos aaptos butanol extract treated and $V$. harveyi challenged post larvae hepatopancreas on six hours post treatment. $E=$ Embryonic cell; $\mathrm{B}=$ Blasenzellen cell; $\mathrm{R}=$ Restzellen cell; $\mathrm{F}=$ Fibrillazellen cell; $\mathrm{G}=$ Necrosis cell; $\mathrm{M}=$ Fatty degeneration; $\mathrm{H}=$ Haemorrhage; $\mathrm{T}=$ Atrophy. Haematoxylin and Eosin staining, magnification $=40 \mathrm{x}$

Findings of the present study suggested that Aaptos aaptos butanol extract could be a potential alternative bioactive compounds source for the development of tiger shrimp, Penaeus monodon post larvae in vibriosis disease therapy. As reported that marine sponge Aaptos aaptos contains alkaloid compounds such as aaptamine, isoaaptamine, and demethyloxyaaptamine (Shaari et al., 2009). Those compounds were found to be inhibit the growth of Gram-positive and Gram-negative bacteria (Rasyid, 2009).

\section{CONCLUSION}

Aaptos aaptos butanol extract at the concentration of $125 \mathrm{mg} / \mathrm{L}$ was significantly able to inhibit the growth of Vibrio harveyi in rearing water and post larvae. This Aaptos aaptos butanol extract treatment also showed lower mortality (43.3\%) than control (80\%). At this concentration, no changing on post larvae hepatopancreas tissue was observed. Based on this study, Aaptos aaptos butanol extract has the potential as bioactive compounds source for treatment of vibriosis.

\section{ACKNOWLEDGEMENTS}

The experiment was funded by South Sulawesi Province Governor, Indonesia and MOSTI, Malaysia with the vote No. 53051. We would like to thank Ridwan and Ulla (Divers of Hasanuddin University's Marine Station) and staffs of Research and Development Institute for Coastal Aquaculture (RICA), Maros for their support during the experiment. 


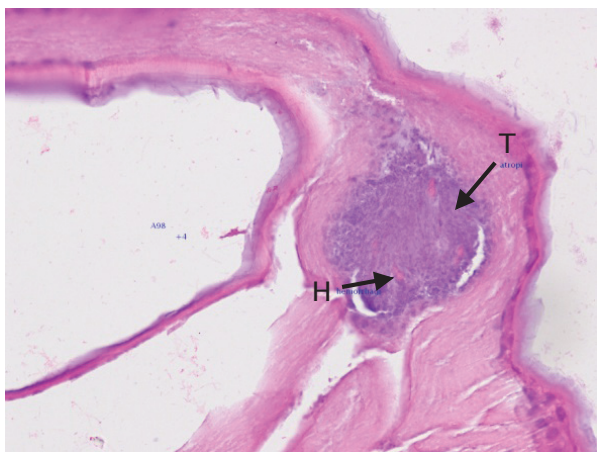

$0 \mathrm{mg} / \mathrm{L}(\mathrm{A})$

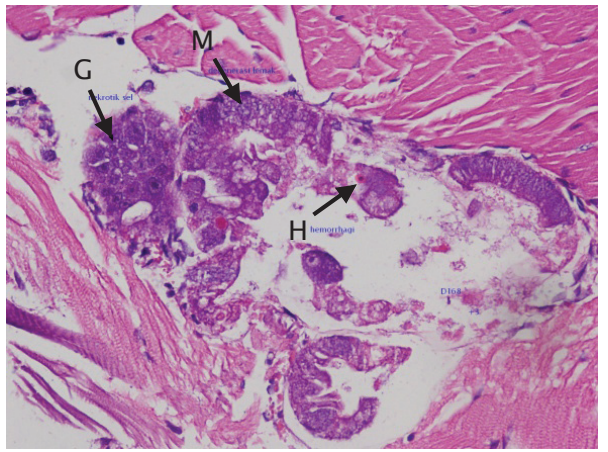

$31.25 \mathrm{mg} / \mathrm{L}(\mathrm{B})$

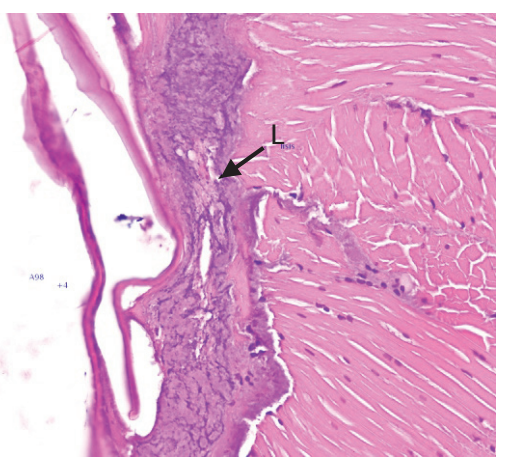

$0 \mathrm{mg} / \mathrm{L}(\mathrm{A})$

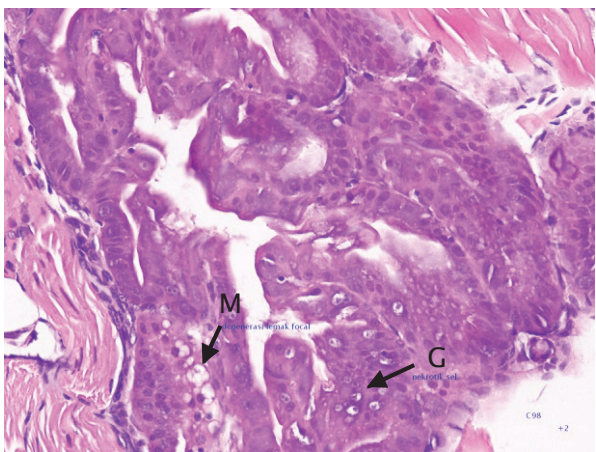

$62.5 \mathrm{mg} / \mathrm{L}(\mathrm{C})$

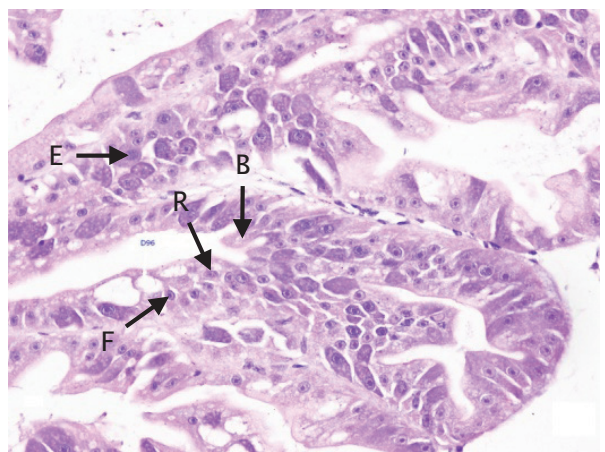

$125 \mathrm{mg} / \mathrm{L}(\mathrm{D})$

Figure 4. Histological observation of Aaptos aaptos butanol extract treated and $V$. harveyi challenged post larvae hepatopancreas 96 hours post treatment. $\mathrm{E}=$ Embryonic cell; $\mathrm{B}=$ Blasenzellen cell; $\mathrm{R}=$ Restzellen cell; $\mathrm{F}=$ Fibrillazellen cell; $\mathrm{G}=$ Necrosis cell $; \mathrm{M}=$ Fatty degeneration; $\mathrm{H}=$ Haemorrhage; $\mathrm{T}=$ Atrophy $\mathrm{L}=$ Lysis. Haematoxylin and Eosin staining, magnification $=40 \mathrm{x}$

\section{REFERENCES}

Agung, M.U.K. (2007). Study of several natural product as antibacterial in vibriosis prevention on black tiger shrimp. Master Thesis. Padjajaran University, Jatinangor.
Ambipillai, L., Sobhana, K.S., George, K.C., \& Sanil, N.K. (2003). Histopathological survey of cultured shrimps in Cochin, Kerala. Journal Marine Biology Association India, 45(2), 178-185. 
Guittat, L., Alberti, P., Rosu, F., van Miert, S., Thetiot, E., Pieters, L., Gabelica, V., De Pauw, E., Ottaviani, A., Roiu, J.F., \& Mergny, J.L. (2003). Interaction of cryptolepine and neocryptolepine with unusual DNA structures. Bioch., 85, 535-541.

Hettiarachchi, M., Pathirage, S.G., \& Hettiarachchi, D.C. (2005). Isolation of the bacterium, Vibrio harveyi from cultured shrimp, Penaeus monodon and production of vaccines against the bacterium. J. Natn. Sci. Foundation, 33(4), 257-263.

Isnansetyo, A., Trijoko, Setyowati, E.P., \& Anshory, H.H. (2009). In vitro antibacterial activity of methanol extract of a sponge, Geodia sp. against oxytetracyclin-resistent Vibrio harveyi and its toxicity. J. Biol. Sci., 9, 224-230.

Jiravanichpaisal, P., Miyazaki, T., \& Limsuwan, C. (1994). Histopathology, biochemistry, and pathogenicity of Vibrio harveyi infecting black tiger prawn Penaeus monodon. J. Aquat. Anim. Health, 6(1), 27-35.

Kadriah, I.A.K. (2012). Development of rapid detection methods of vibriosis diseases in penaeid shrimp aquaculture. Ph.D Thesis. Institute Pertanian Bogor. Bogor, 104 pp.

Kumar, S.T., \& Ramalingan, K. (2014). Trial vaccine and immune function analysis of Penaeus monodon against Vibrio harveyi and Vibrio parahaemolyticus. Research J. of Pharm., Biological and Chem. Sci. 5(3), 111.

Mariyono, A., Wahyudi, \& Sutomo. 2002. Prevention technique of luminescent shrimp disease through bacterium population control in. Buletin Teknik Pertanian, 7(1), 2527.

Nash, G., Nithimathachoke, C., Tungmandi, C., Arkarjamorn, A., Prathanpipat, P., \& Ruamthaveesub, P. (1992). Vibriosis and its control in pond-reared Penaeus monodon in Thailand. In Shariff, M., Subasinghe, R.P., \& Authur, J.R. (Eds.), Diseases in Asian Aquaculture 1. Fish Health Section, Asian Fisheries Society, Manila. Philippines, p. 143-155.

Ninawe, A.S. (2007). Marine organisms are a promising new source of bioactive substances. Drug Discovery \& Development Magazine, 10(2), 46-49.

Parado-estepa. F.D., Quinitio, E.T., \& Borlongan, E.L. (1996). Prawn hatchery operations. Aquaculture Department, Southeast Asian
Fisheries Development Center. Tigbauan, Iloilo. Philippines, 36 pp.

Pasharawipas. (2011). Inducible viral receptor, A possible concept to induce viral protection in primitive immune animals. Virology Journal, 8, 326.

Raffi, S.M., \& Suresh, T.V. (2011). Screening of chloramphenicol in wild and cultured shrimp Penaeus monodon by competitive enzyme linked immunosorbent assay. In International Conference on Chemical, Biological and Environment Sciences (ICCEBS'2011). Bangkok.

Ramesh, K., Natarajan, M., Sridhar, H., \& Umamaheswari, S. (2014). Virulence determination among Vibrio harveyi hatchery isolates through haemolysis and growth constraint. Global J. of Bio-Science and Biotechnology, 3(1), 109-114.

Rasyid, A. (2009). Bioactive compounds from sponge. Oseana, XXXIV(25), 25-32.

Sarjito, Ningrum, N.E.W., Radjasa, O.K., \& Prayitno, S.B. (2012). Application of repetitive sequence-based PCR on the richness of vibrio on the tiger shrimp (Penaeus monodon Fab.). J. of Coastal Development, 15(3), 303-309.

Sarma, K., \& Devi, J. (2012). Changes in the seminiferous epithelium of the testes during postnatal development in Assam goat. Anatomi Research International. Doi:10. $1155 / 2012 / 620924$.

Selvin, J., \& Lipton, A.P. (2004). Dendrillanigra, a marine sponge, as potential source of antibacterial substances for managing shrimp diseases. Aquaculture, 236, 277 283.

Shaari, K., Ling, K.C., Rashid, Z.M., Jean, T.P., Faridah, A., Salahuddin, M.R., Zaenal, Z., Lajis, N.H., Habsah, M., \& Ali, A.M. (2009). Cytotoxic aaptamines from Malaysian Aaptos aaptos. Mar. Drugs., 7, 1-8.

Soundarapandian, P., Sankthivel, K., \& Dinakaran, G.K. (2009). Culture of Penaeus monodon (Fabricus) by using cyclop-Eeze Feed. Current Research Journal of Biological Science, 1(3), 113-117.

Traifalgar, R.F.M., Corre, V.L., \& Serrano, A.E. (2013). Efficacy of dietary immunostimulants to enhance the immunological responses and Vibriosis resistance of juvenile Penaeus monodon. Journal of Fisheries and Aquatic Science, 8(2), 340-354. 